\title{
STUDI RELEVANSI MATERI SHEET METAL FORMING DI SMK DAN DI DPTM BERDASARKAN MATERI STANDAR UJI KOMPETENSI KEAHLIAN
}

\author{
Raden N. Virani Putri ${ }^{1}$, Ariyano ${ }^{2}$, Mumu Komaro ${ }^{3}$ \\ Universitas Pendidikan Indonesia \\ Jl. Dr. Setiabudhi No. 229 Bandung 40154 \\ arnviranip@yahoo.com
}

\begin{abstract}
ABSTRAK
Prinsip relevansi merupakan salah satu dari prinsip pengembangan kurikulum, sebagai pedoman agar kurikulum terus selaras dengan perkembangan jaman. Tujuan penelitian ini untuk menghasilkan deskripsi relevansi materi, dan pemetaan sekuen dari ketiga materi Sheet Metal Forming yang terdapat di DPTM, SMK Teknologi Pesawat Udara dan uji kompetensi. Metode penelitian yang digunakan adalah deskriptif kuantitatif. Relevansi materi Sheet Metal Forming antara DPTM, SMK Teknologi Pesawat Udara dan Uji Kompetensi Keahlian Konstruksi Badan Pesawat Udara dan pemetaan materi diperoleh melalui hasil penelitian yang kemudian dipaparkan dan dibahas. Materi Sheet Metal Forming di DPTM relevan dengan predikat memuaskan karena nilai recall lebih kecil dari nilai precision pada materi Sheet Metal Forming di SMK, dan keduanya relevan pula pada materi Standar Uji Kompetensi Keahlian Konstruksi Badan Pesawat Udara dengan predikat memuaskan karena nilai recall lebih kecil dari nilai precision.
\end{abstract}

Kata kunci: relevansi, pemetaan, sheet metal forming, kompetensi

\section{PENDAHULUAN}

Hasiln pengalaman yang diperoleh ketika melaksanakan Program Pengalaman Lapangan (PPL) di SMK teknologi, terdapat beberapa hambatan yang muncul ketika pelaksanaan kegiatan tersebut. Terlihat dari hasil pengamatan yang dilakukan di Workshop Konstruksi Badan Pesawat Udara (KBPU) SMK Negeri 12 Bandung bahwa beberapa mahasiswa praktikan PPL kesulitan dalam menyampaikan materi tentang Kontruksi Badan Pesawat Udara. Hal ini dapat terjadi disebabkan beberapa faktor diantaranya bisa jadi mahasiswa praktikan ini tidak siap untuk mengajar praktikum Konstruksi Badan Pesawat Udara atau mahasiswa tersebut kurang menguasai materi tersebut.

Menurut hasil wawancara terhadap guru pamong dan tiga mahasiswa praktikan PPL yang ditempatkan di Workshop KBPU, guru pamong menyebutkan bahwa mahasiswa praktikan PPL masih belum siap untuk terjun langsung dan mengajar materi mengenai Aircraft Sheet Metal Forming kepada siswa baik teori maupun praktik. Hal ini terjadi karena banyak materi yang belum diketahui dan dipelajari oleh mahasiswa praktikan PPL, sehingga sebelum mahasiswa praktikan diberikan tanggung jawab mengajar harus diberikan pembelajaran awal

\footnotetext{
${ }^{1}$ Mahasiswa Departemen Pendidikan Teknik Mesin FPTK, UPI

${ }^{2}$ Dosen Departemen Pendidikan Teknik Mesin FPTK, UPI

${ }^{3}$ Dosen Departemen Pendidikan Teknik Mesin FPTK, UPI
} 
dan penyesuaian dengan materi yang akan diajarkan kepada siswa. Ketidaksiapan mahasiswa yang diakibatkan oleh kurangnya penguasaan materi ini tidak sejalan dengan prinsip relevansi eksternal. Tujuan, isi, dan proses belajar yang tercakup dalam kurikulum hendaknya relevan dengan tuntutan, kebutuhan dan perkembangan masyarakat (Sukmadinata, 2015). Relevansi ini dimaksudkan pembelajaran di perguruan tinggi hendaknya relevan dengan pembelajaran di SMK untuk memenuhi kebutuhan dan tuntutan kurikulum yang terdapat di SMK.

Ketidaksiapan mahasiwa praktikan dalam mengajar secara tidak langsung juga berdampak kepada hasil uji kompetensi siswa. Apabila nilai rata-rata kelas hasil uji kompetensi program keahlian Konstruksi Badan Pesawat Udara dijadikan acuan kelulusan uji kompetensi, maka sekitar 112 siswa dinyatakan belum lulus uji kompetensi. Jumlah tersebut hampir separuhnya belum lulus uji kompetesi dari 227 siswa.

Teknologi Pesawat Udara pembentukan logam dengan mata pelajaran produktif di SMK Teknologi Pesawat Udara. Sejalan dengan prinsip relevansi, materi pada mata pelajaran produktif SMK Teknologi Pesawat Udara khususnya mengenai Konstruksi Badan Pesawat Udara haruslah sesuai dengan materi Sheet Metal Forming DPTM FPTK UPI. Mata pelajaran tersebut berkaitan dengan beberapa mata kuliah diantaranya Teknik Pembentukan Logam, Gambar Teknik, Teknik Pengelasan dan Fabrikasi/Pengerjaan Logam. Sebagai calon guru di SMK diharapkan lulusan dari lembaga ini yang akan memberikan materi di SMK Teknologi Pesawat Udara tersebut. Apabila materi yang diberikan kepada mahasiswa praktikan PPL dibangku perkuliahan tidak sesuai dengan materi yang diberikan oleh guru kepada siswa di SMK Teknologi Pesawat Udara, maka hal yang akan terjadi adalah mahasiswa praktikan PPL tidak siap untuk mengajar siswa di SMK Teknologi Pesawat Udara.

Selain itu, seorang mahasiswa praktikan PPL yang berorientasi pada figur guru profesional haruslah memiliki pengetahuan dan keterampilan yang sesuai dengan bidang yang diampunya, sehingga mahasiwa praktikan PPL dapat berlatih menjalankan tugasnya sebagai guru profesional seperti yang telah disebutkan pada Undang-undang Republik Indonesia Nomor 14 Tahun 2005 tentang Guru dan Dosen. Materi yang akan diteliti dikhususkan pada materi standar uji kompetensi program keahlian Konstruksi Badan Pesawat Udara di SMKN 12 Bandung.

Kurikulum sendiri seperti yang tercantum pada Peraturan Pemerintah Nomor 15 Tahun 2015, berbentuk sebuah rencana dan pengaturan yang didalamnya berisi tujuan, isi, materi 
ajar, dan cara penyampaiannya dan merupakan pedoman pelaksanaan kegiatan pembelajaran untuk mewujudkan tujuan pendidikan. Kurikulum hendaknya dapat berkembang dari berbagai aspek mengikuti perkembangan jaman (Bobbitt and Thornton, 2004). Salah satu prinsip yang mendukung pengembangan kurikulum adalah prinsip relevansi. Prinsip relevansi kemudian dibagi ke dalam dua, yakni prinsip relevansi eksternal dan relevansi internal. Relevansi eksternal ini dimaksudkan bahwa tujuan, isi dan proses belajar uang tercakup dalam kurikulum hendaknya relevan dengan tuntutan, kebutuhan, dan perkembangan masyarakat. Kurikulum menyiapkan siswa untuk bisa hidup dan bekerja dalam masyarakat. Hal-hal yang tertuang dalam kurikulum hendaknya mempersiapkan siswa untuk tugas tersebut. Kurikulum bukan hanya menyiapkan anak untuk kehidupannya sekarang tetapi juga untuk masa depannya. Kurikulum juga harus memiliki relevansi internal yakni kesesuaian atau konsisten antara komponen-komponen kurikulum, yaitu antara tujuan, isi, proses penyampaian, dan penilaian (Munir, 2010). Relevansi ini menunjukan suatu keterpaduan kurikulum. Prinsipprinsip pengembangan kurikulum lainnya adalah prinsip fleksibilitas, prinsip kontinuitas, prinsip praktis dan prinsip efektivitas. Suatu sistem temu balik informasi dapat dikatakan efektif apabila rasio recall dan precision sama besarnya (Laoli, 2009). Hasil yang diperoleh dapat dikatakan memuaskan apabila nilai rasio precision tinggi walaupun nilai rasio recall-nya rendah.

\section{METODE PENELITIAN}

Metode penelitian yang digunakan adalah metode penelitian deskriptif kuantitatif. Penelitian deskriptif digunakan untuk memperoleh informasi tentang status gejala saat penelitian dilakukan. Penelitian ini diarahkan untuk menetapkan sifat suatu situasi pada waktu penyelidikan itu dilakukan. Tidak ada perlakuan yang diberikan atau dikendalikan pada penelitian deskriptif seperti yang dapat ditemui dalam penelitian lain. Adapun pertimbangan memilih metode ini, yakni untuk mengetahui tingkat relevansi materi sheet metal forming di DPTM dan di SMK Teknologi Pesawat Udara serta perbandingannya dengan materi Uji Kompetensi Keahlian KBPU.

Subjek penelitian yang pertama yaitu materi sheet metal forming di DPTM yang terbagi dalam tiga Mata Kuliah Konsentrasi (MKK) dan satu Mata Kuliah Perluasan dan Pendalaman (MKPP). Subjek penelitian kedua yaitu materi teknik pembentukan dan fabrikasi logam 
lembaran di SMK yang tergabung pada suatu program keahlian di SMK Teknologi Pesawat Udara yakni Konstruksi Badan Pesawat Udara. Subjek penelitian ketiga yaitu materi Uji Kompetensi Keahlian yang diterbitkan oleh BSNP. Subjek pertama terdiri dari mata kuliah Gambar Teknik dijabarkan ke dalam 12 materi inti sedangkan mata kuliah Fabrikasi Logam/ Pengerjaan Logam dijabarkan ke dalam tujuh materi inti. Kemudian mata kuliah Teknik Pembentukan Logam diuraikan ke dalam enam materi inti dan mata kuliah Teknik Pengelasan diuraikan kedalam empat materi ini. Jumlah keseluruhan materi inti yang terdapat pada mata kuliah di DPTM adalah 29 materi inti.

Subjek kedua terdiri dari mata pelajaran Gambar Teknik dijabarkan ke dalam enam materi inti sedangkan mata pelajaran Aircraft Welding dijabarkan ke dalam 14 materi inti. Kemudian mata pelajaran Aircraft Sheet Metal Forming diuraikan ke dalam enam materi inti dan mata pelajaran Gambar Bukaan dan Bentangan diuraikan kedalam lima materi ini. Jumlah keseluruhan materi inti yang terdapat pada mata kuliah di DPTM adalah 15 materi inti. Subjek ketiga terdiri dari 4 topik, yakni gambar teknik, gambar bukaan dan bentangan, pengelasan OA/GTAW, dan Aircraft Sheet Metal Forming. Ke-empat topik tersebut kemudian dibagi kembali menjadi 14 pokok bahasan.

\section{HASIL PENELITIAN}

Diperoleh hasil penelitian bahwa materi sheet metal forming di DPTM telah sesuai dengan materi yang dipelajari di SMK Teknologi Pesawat Udara. Relevansi tersebut kemudian diuji menggunakan rumus Fosket. Recall ratio adalah 0,57 dan precision ratio adalah 1, artinya bahwa recall ratio lebih kecil dari precision ratio. Suatu sistem informasi dapat dikatakan efektif apabila rasio antara recall dan precision seimbang, ataupun apabila nilai precision lebih besar recall pun, sistem tersebut dapat dikatakan memuaskan (Laoli, 2009). Berdasarkan perhitungan diatas, mendapati bahwa besarnya precision lebih besar dari recall. Hal ini dapat dikatakan bahwa sistem ini memuaskan.

Hasil penelitian lainnya yaitu materi Uji Kompetensi Keahlian KBPU sudah relevan dengan materi yang diajarkan di DPTM. Relevansi materi Uji Kompetensi Keahlian KBPU Tahun pelajaran 2015/2016 telah relevan dengan materi sheet metal forming yang diberikan di DPTM. Hal ini berarti bahwa materi sheet metal forming di DPTM telah sepenuhnya mencakup materi yang dibutuhkan siswa sebagai bekal pada pelaksanaan Uji Kompetensi 
Keahlian KBPU. Relevansi tersebut kemudian diuji menggunakan rumus Fosket, hasilnya sebagai berikut: recall ratio adalah 0,27 dan precision ratio adalah 1 , artinya bahwa recall ratio lebih kecil dari precision ratio. Berdasarkan perhitungan diatas, mendapati bahwa besarnya precision lebih besar dari recall. Hal ini dapat dikatakan bahwa sistem ini memuaskan.

Relevansi materi sheet metal forming di SMK Teknologi Pesawat Udara dengan materi Uji Kompetensi Keahlian KBPU. Materi sheet metal forming yang diberikan di SMK Teknologi Pesawat Udara secara keseluruhan telah mencakup materi-materi yang digunakan pada Uji Kompetensi Keahlian KBPU. Materi Uji Kompetensi Keahlian KBPU ini mengacu pada materi-materi yang dipelajari di SMK Teknologi Pesawat Udara, sehingga tidak banyak ditemukan perbedaan diantara kedua subjek ini. Uji Kompetensi Keahlian KBPU sendiri merupakan ajang untuk mengevaluasi kompetensi siswa selama menempuh pendidikan di SMK Teknologi Pesawat Udara bidang keahlian KBPU. Relevansi tersebut kemudian diuji menggunakan rumus Fosket, hasilnya sebagai berikut: recall ratio adalah 0,6 dan precision ratio adalah 1, artinya bahwa recall ratio lebih kecil dari precision ratio. Berdasarkan perhitungan tersebut, bahwa besarnya precision lebih besar dari recall. Hal ini dapat dikatakan bahwa sistem ini memuaskan.

\section{PEMBAHASAN}

Relevansi antara materi sheet metal forming di SMK Teknologi Pesawat Udara dan di DPTM secara keseluruhan sudah relevan. Hal ini dapat dilihat pada tabel pemetaan materi yakni relevansi materi berdasarkan mata pelajaran di SMK Teknologi Pesawat Udara. Terlihat bahwa mata pelajaran Gambar Teknik di SMK Teknologi Pesawat Udara telah relevan dengan materi yang ada di DPTM, dengan predikat memuaskan. Ada beberapa materi praktik di SMK Teknologi Pesawat Udara yang tidak diberikan di SMK Teknologi Pesawat Udara yakni, praktik gambar perspektif, gambar proyeksi trimetri dan gambar proyeksi miring (oblique) (Kemendikbud RI, 2013).

Beberapa materi di SMK Teknologi Pesawat Udara hanya diberikan teorinya saja, tidak dengan praktiknya, yakni pada mata pelajaran Aircraft Sheet Metal Forming tidak memberikan praktikum yang menggunakan template, dan pada mata pelajaran Aircraft Welding tidak memberikan praktikum mengenai pengelasan GMAW dan beberapa cacat las 
diantaranya incomplete penetration, excess reinforcement, cold lap, under fill, star crack, spatter, surface porosity, tungsten inclusion, weaving fault, dan excessive penetration. Hal ini terjadi karena tidak tersedianya fasilitas di SMK Teknologi Pesawat Udara, sehingga materimateri yang telah disebutkan sebelumnya tidak dapat dilaksanakan praktikum (Idi, 2006).

Relevansi materi Uji Kompetensi Keahlian KBPU pun relevan dengan materi yang ada di DPTM. Hal ini ditunjukan pada tabel relevansi materi Uji Kompetensi Keahlian KBPU terhadap materi di DPTM. Pemetaan pada lampiran tersebut menunjukan bahwa seluruh materi yang terdapat pada Uji Kompetensi Keahlian KBPU telah diberikan juga di DPTM dengan predikat memuaskan sehingga guru PPL DPTM yang mengajar di SMK Teknologi Pesawat Udara dapat dinyatak sudah mempunyai bekal yang cukup dari segi materi, minimal untuk memberikan materi yang dibutuhkan pada Uji Kompetensi Keahlian KBPU. Hal ini selaras dengan teori relevansi kurikulum yang sebelumnya telah dikemukakan oleh Sukmadinata (2015), yakni kurikulum yang dibuat tentu saja harus relevan dengan kebutuhan dan tuntutan yang ada di masyarakat. Dalam kasus ini materi DPTM telah memenuhi kebutuhan materi yang dibutuhkan oleh siswa sebagai bekal dalam melaksanakan Uji Kompetensi Keahlian KBPU. Selain itu, relevansi materi ini juga selaras dengan prinsip kontinuitas pada kurikulum, yakni kurikulum antar jenjang pendidikan haruslah selaras, mengingat banyaknya siswa SMK khususnya, SMK Teknologi Pesawat Udara yang melanjutkan studi di DPTM.

Relevansi materi Uji Kompetensi Keahlian KBPU juga sudah relevan dengan materi yang diberikan di SMK Teknologi Pesawat Udara. Hasil menunjukan bahwa tingkat relevansi materi Uji Kompetensi Keahlian KBPU terhadap materi sheet metal forming di SMK Teknologi Pesawat Udara telah mencapai predikat memuaskan. Hal ini dapat diartikan bahwa materi yang diujikan pada Uji Kompetensi Keahlian KBPU, telah sepenuhnya diberikan pula di SMK Teknologi Pesawat Udara. Berdasarkan pada tujuan dilaksanakannya Ujian Kompetensi Keahlian yang disebutkan oleh BSNP bahwa Uji Kompetensi Keahlian ini bertujuan untuk mengukur pencapaian kompetensi siswa SMK yang akan menyelesaikan pendidikannya. Untuk itu materi yang terdapat pada Materi Standar Uji Kompetensi Keahlian pun diadaptasi dari kurikulum SMK Teknologi Pesawat Udara itu sendiri (Hamalik, 2010). 


\section{KESIMPULAN}

Penelitian ini dapat disimpulkan bahwa materi sheet metal forming di SMK Teknologi Pesawat Udara dan di DPTM FPTK UPI sudah relevan dengan materi standar Uji Kompetensi Keahlian KBPU dengan predikat memuaskan. Relevansi materi pada teori sheet metal forming yang terdapat di SMK Teknologi Pesawat Udara relevan terhadap materi sheet metal forming yang diberikan di DPTM dengan predikat memuaskan, walaupun pada konten praktiknya masih ada beberapa materi di DPTM yang belum secara utuh meng-cover materi di SMK Teknologi Pesawat Udara tersebut.

\section{REFERENSI}

Bobbitt, F. D.J., and Thornton, S.J. (2004). The curriculum studies reader (Second Edition). New York: Routledge Falmer.

Hamalik, O. (2010). Manajemen pengembangan kurikulum. Bandung: Remaja Rosdakarya.

Idi, A. (2006). Pengembangan kurikulum teori \& praktik. Yogyakarta: Ar-Ruzz Media.

Kemendikbud RI. (2013). Aircraft sheet metal forming (XI Semester 3) [Online]. Tersedia: http://www.scribd.com/mobile/doc/279539658/Aircraft-Sheet-Metal-Forming (Diakses pada Tanggal 22 November 2016).

Laoli, F. (2009). Analisis tingkat relevansi e-journal pada database american society of civil engineer (ASCE) dalam memenuhi kebutuhan informasi mahasiswa magister teknik sipil di Universitas Sumatera Utara. Departemen Studi Ilmu Perpustakaan dan Informasi, Fakultas Sastra, Universitas Sumatra Utara, Medan. Tersedia: http://repository.usu.ac.id/xmlui/handle/123456789/17855 (diakses pada tanggal 1 November 2016).

Munir. (2010). Kurikulum berbasis teknologi informasi dan komunikasi. Bandung: Alfabeta.

Sukmadinata, N. S. (2015). Pengembangan kurikulum teori dan praktik. Bandung: Remaja Rosdakarya. 